\title{
Flemish Cinema and Film Culture through South African Eyes
}

\author{
By Martin P. Botha \\ Fall 2007 Issue of KINEMA
}

\section{THE HERITAGE OF FILM: PERSPECTIVE ON FLEMISH CINEMA AND FILM CUL- TURE THROUGH SOUTH AFRICAN EYES}

I assisted the Locarno Film festival in 2005 with a retrospective of short films by young South African directors. There I met a very talented, young Flemish director, whose film was by far the best in the one section. ${ }^{(1)}$ It moved me immensely with its honest portrait of alienation and racial discrimination.

We had a long discussion on film history, aesthetics and film cultures. We also talked about the history of film in Belgium and it was noted that while the French speaking side of Belgian cinema had recently received international acclaim (for example, the work by the Dardenne Brothers), Flemish cinema was struggling. In fact, the young filmmaker made the statement that there was little to be excited about in the history of Flemish cinema. He felt especially that the films about rural communities and most of the historical dramas were not saying much about contemporary Flanders, in particular, the youth.

I have heard this argument before, but in a totally different cultural context. Many young, aspiring South African filmmakers have told me there is very little in South African film history which makes them proud of their film culture. For decades South African film culture has been in isolation. The years 1959 to 1980 were characterised by an artistic revival in filmmaking throughout the world, ranging from exciting political films in Africa and Latin America to examples of great art cinema in Europe and Asia. National cinemas ${ }^{(2)}$ emerged in Australia, West Germany, Iceland and New Zealand. Unfortunately, due to moral and political censorship, a severe lack of audience development and inadequate film distribution, South Africans and thus local filmmakers were not exposed to these remarkable developments in world cinema. We made hundreds of Afrikaans language soap operas instead during this time, while the world, including several African countries, explored the artistic, social and political possibilities of the medium to the fullest!

Furthermore, the painful reality of South African filmmaking between 1895 and 1994 was that in many ways black South Africans were excluded. Black South Africans had no money to make films. They had no access to equipment. Opportunities were almost non-existent for black scriptwriters or directors to create their own images on the screen. And apartheid policy led to a very fragmented film industry (see Botha 2004). Thus, for many young black filmmakers there is very little to be excited about in South African film history, with the exception of a few names such as Lionel Ngakane. (3)

What the young, aspiring South African filmmakers totally forget is that, among the decades of film escapism, racist films and government propaganda, South African cinema has produced cinematic jewels. Although 1994 saw the birth of democracy in South Africa, our film industry is much older; in fact, our great documentary film tradition dates back to 1896 and the Anglo Boer War ${ }^{(4)}$. We shouldn't forget those filmmakers who created films against all the odds. Jans Rautenbach (Jannie Totsiens) $^{(5)}$, Ross Devenish (Marigolds in August) ${ }^{(6)}$ and the younger generation of the 1980s challenged moral and political censorship, a severe lack of audience development and inadequate film distribution to shape progressive texts, which became the foundation of a new, critical South African cinema during the 1990s. ${ }^{(7)}$

Since the late 1970s and the early 1980s, a group of film and video producers and directors who were not affiliated to the established film companies in the mainstream film industry, made films and videos about the socio-political realities of the majority of South Africans (Botha \& Van Aswegen 1992; Blignaut \& Botha 1992). Some of these films were shown at local film festivals such as the Durban and Cape Town International Film Festivals, and from 1987 until 1994, the Weekly Mail Film Festival. Other venues included universities, church halls, trade union offices and the private homes of interested parties. Many of the films experienced censorship problems during the State of Emergency during the 1980s, and some were banned.

The films had small budgets and were either financed by the producers themselves, by progressive organisations (such as the International Defence and Aid Fund for South Africa for a united, democratic, non-racial 


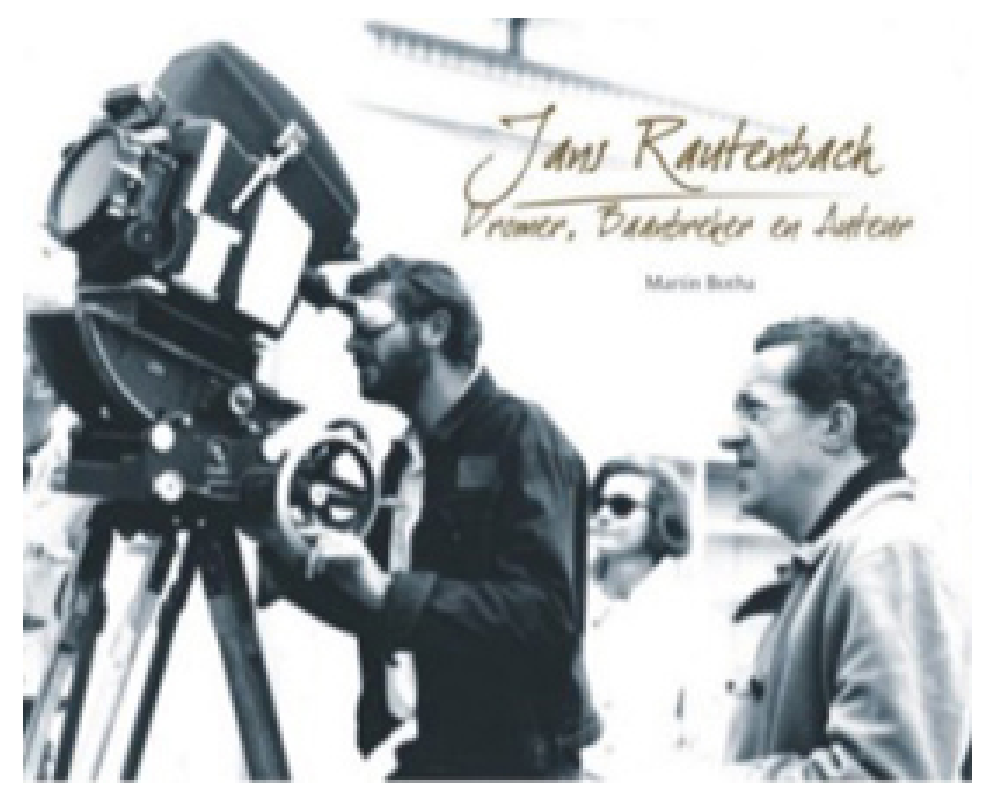

Figure 1: Director Jans Rautenbach at work

South Africa) and overseas television stations. These films were chiefly the product of two groups that emerged jointly: a group of white university students opposed to apartheid, and black workers who yearned for a film or video form using indigenous imagery that would portray their reality in South Africa and give them a voice and space in local films ${ }^{(8)}$. Together with numerous documentaries, community videos and full-length films such as Mapantsula, short films and even animation work marked the beginning of a new, critical South African cinema. The foundations were laid for a post-apartheid cinema!

Initially this new cinema was based on audio-visual material that reflected the realities of the black majority of South Africa in their aspirations and struggle for a democratic society. Since the beginning of the 1990s other marginalized voices were added to these documentaries and short films, for example those of women, gays and lesbians, and even the homeless. It is from these films and videos that the symbols and iconography of a national South African film industry can be drawn, rather than from the diversions produced by the Afrikaans cinema of the 1960s and 1970s, or the made-for-blacks cinema of the 1970s. Most of the new critical local films, features or short films can be described as progressive film texts in the sense that the majority of them are consciously critical of racism, sexism or oppression. They dealt with the lives and struggle of the people in a developing country and were mostly allied with the liberation movements for a non-racial, non-sexist South Africa.

Some of these films (short, features and documentaries) also dealt with events that were conveniently left out in official South African history books or in a contemporary context in actuality programmes on national television under control of the Nationalist regime. Therefore, they became guardians of popular memory within the socio-political process in South Africa.

Post-apartheid cinema is characterized by the emergence of new voices and a diversification of themes. One thinks of a new generation of filmmakers such as Zola Maseko (The Life and Times of Sara Baartman, Drum), Ntshavheni Wa Luruli (Chikin Biznis - The Whole Story, The Wooden Camera), Akin Omotoso (God is African), Teboho Mahlatsi (Portrait of a Young Man Drowning, Yizo Yizo), Dumisani Phakhati (Christmas with Granny, Waiting for Valdez), Ramadan Suleman (Fools, Zulu love letter), Sechaba Morojele (Ubuntu's Wounds), Gavin Hood (A Reasonable Man), Zulfah Otto Sallies (Raya), Riaan Hendricks (A Fisherman's Tale), Khalo Matabane (Chikin Biznis), Jason Xenopoulos (Promised Land), Madoda Ncayiyana (The Sky in Her Eyes), Thabang Moleya (Portrait of a Dark Soul) and Norman Maake (Soldiers of the Rock).

For the first time South African audiences are exposed to certain marginalized communities, such as the homeless in Francois Verster's remarkable documentary Pavement Aristocrats: The Bergies of Cape Town 
(1998), the Himbas of Kaokoland in Craig Matthew's Ochre and Water (2001), AIDS victims in Shouting Silent (2001), the gay subcultures of the fifties and sixties in The Man Who Drove With Mandela (1998) and the San Bushmen in the Foster Brothers' visual poem The Great Dance. (1999). Another important theme in post-apartheid cinema is how South Africans are dealing with the traumatic past and how they are adjusting to the dramatic socio-political changes in contemporary South African society.

Film schools have become vital in a post-apartheid South African cinema to expose students to international cinema, as well as to focus on the technological, social, aesthetical and political highlights in the development of cinema in all its facets. Apart from skills training South African film schools have the responsibility to nurture new voices in an industry, which has a long history in which many voices were silenced - those from the black majority, women, gays and lesbians. ${ }^{(9)}$ Film is not only for getting bums on seats, but also a means of self-expression by voices which were silent during the apartheid years. Those voices could belong to blacks, women, gays and lesbians, and others, who never had the opportunity to express themselves in the cinema under apartheid.

But, my article is not about South Africa, but Belgium and in particular Flemish cinema. I want to come back to the statement of the young Flemish film director, that there is little to celebrate in the Flemish Film Culture. I have to disagree. Being a teacher of film history at tertiary institutions in Cape Town I do explore various film cultures and industries, from Argentina to Zimbabwe. I do look at the work of all the international directors, from Antonioni to Fred Zinnemann. I would make a sincere attempt to explore populist Hollywood cinema, as well as the most challenging work by a Sokurov or Bela Tarr. My interest in Flemish cinema started in the early 1990s, when I got involved with a project by Kris Govaerts, a very talented student at the Vrije Universiteit Brussel. He was working on a thesis on Cinema and Apartheid and how progressive filmmakers in South Africa have attempted to depict the socio-political realities in South Africa during apartheid. ${ }^{(10)}$ Thanks to Kris I met his promoter, Prof. Hubert Dethier, one of the greatest scholars I have ever met and a brilliant writer on film studies. A professional relationship and a great friendship started.

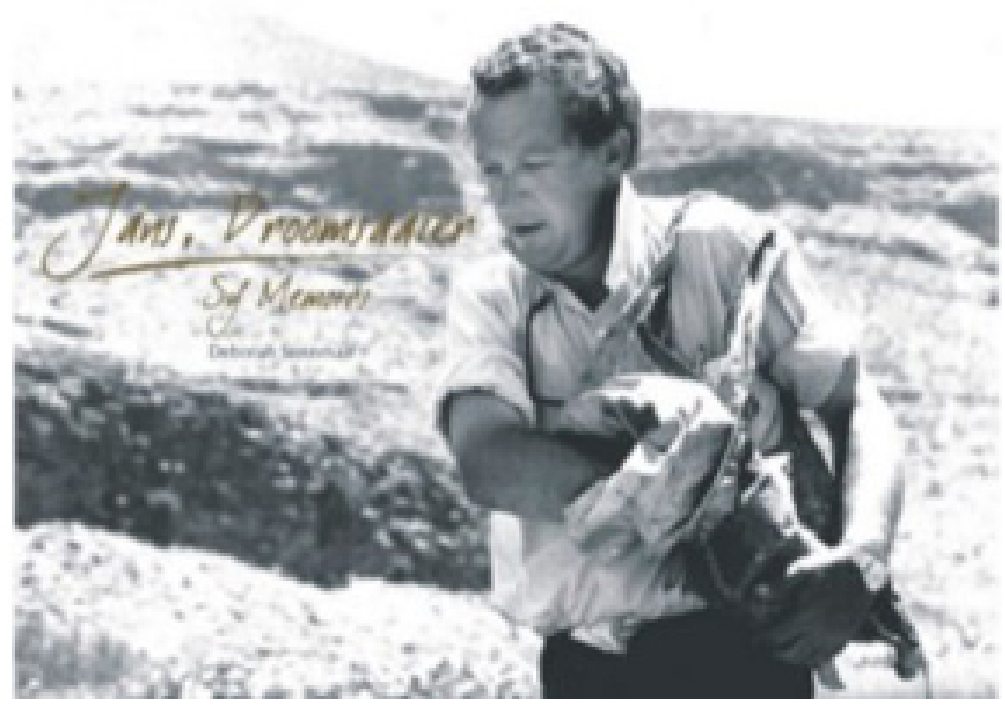

Figure 2: Director Jans Rautenbach

In 1996 Hubert and I published a book on a progressive South African director, Manie van Rensburg, in Flemish. ${ }^{(11)}$ Van Rensburg was initially not part of the movement of anti-apartheid filmmaking. He made drama series for the South African Broadcasting Corporation (SABC) from the mid-1970s until 1987. The advent of television in South Africa during 1976 gave many local filmmakers artistic opportunities that had not been available due to the ineffective subsidy scheme. Although censorship regarding political material was very tight at the SABC, Van Rensburg could make artistically successful drama series and 
films. This relationship with the SABC, however, was cut after Van Rensburg decided to join 52 prominent South Africans in 1987 to travel to Dakar, Senegal, in order to have discussions with members of the then banned ANC. The 52 South Africans comprised Afrikaans-speaking people like Van Rensburg's friend, Van Zyl Slabbert, a prominent opposition political figure of the 1980s. The conference in Dakar was a joint undertaking between the Institute for Democratic Alternatives in South Africa (Idasa) and the ANC, and discussions about a liberated economy, the form of a liberated government and solutions to South Africa's conflict took place. When Van Rensburg returned to South Africa, he found himself out of work at the SABC. For two years he couldn't work. With the establishment of the Film and Allied Workers' Organisation he hoped to find a sympathetic, progressive group to support him in his work. The Native Who Caused All the Trouble (1989), a film about a black man's struggle to get his land back due to racist colonial legislation, was his contribution to the new critical, anti- apartheid cinema of the 1980s, and it established him as part of the new movement.

Van Rensburg's oeuvre should also be seen as chronicles of the Afrikaner psyche during three significant periods; firstly, the 1930s and the trauma of urbanisation and struggle to retain the land; secondly, the revival of Afrikaner nationalism during South Africa's involvement in the Second World War; and thirdly, the modern, urban Afrikaner of the 1970s and 80s. In studying especially Van Rensburg's period dramas set in rural areas with a strong emphasis on social concerns, I have noted similarities in Flemish films and these aspects started to intrigue me. Van Rensburg was working mainly in the Afrikaans language, which makes comparisons with the Flemish films even more interesting.

Dramas such as Verspeelde Lente (1982), and Die perdesmous (1983) are noted for their humane treatment of the characters, including outcasts, which are usually in conflict with the societies in which they live. Verspeelde Lente upset Afrikanerdom with its images of poor, lower class Afrikaners at the beginning of the previous century. The misery of the characters and their struggles are, however, set against beautifully filmed South African landscapes. Watching Robbe De Hert's brilliant De Witte van Sichem (1980), one could note how a classical novel ${ }^{(12)}$ could be turned into a piece of socially conscious filmmaking. De Hert's progressive ideological background and his involvement in Fugitive Cinema clearly played an important role to create a disturbing portrait of the poverty in rural Flanders in 1900. The images of social oppression are vivid and have reminded me of the work by our Van Rensburg.

The strongest point of contact between Afrikaans and Flemish cinema is within the so-called genre of those rural dramas, which explore the poverty, social circumstances and struggles of the characters, usually set in the past. Van Rensburg always made the ideological point in his work that the Afrikaner ${ }^{(13)}$ should get out of his own lager, his own prison, a mindset characterized by idealistic conservatism. Within our cultural context this was characterised by an attachment to the past, to ideals of linguistic and racial purity and to religious and moral norms.

From this perspective it is enlightening to witness the ending of Mira (1971): To watch an emancipated woman getting out of a lager and driving across a bridge into a less repressive world, is a very touching experience. And to witness the two marginalized characters, who were raped, exploited and abused by a brutal social system, simply getting up once again in the closing sequence and just going on, in De loteling (1975) is an unforgettable moment in any cinema.

Flemish film history is indeed rich. Apart from the rural dramas there are the urban landscapes of Brussels by Night (1983) and Verbrande Brug (1975), in which marginalized characters are magnificently depicted. The green evocative landscapes of Mira, De loteling and many other rural dramas are replaced by industrial wastelands in Verbrande Brug or the urban nightlife in Brussels by Night. One notes a strong, socially conscious cinema in the work from the directors of Fugitive Cinema, which later had an impact on filmmaking in Belgium parallel to the rural dramas.

In addition to this diversity, one also notes the auteurism of André Delvaux, Harry Kümel and Dominique Deruddere, who eventually created auteur films with an international appeal. Films such as De man die zijn haar kort liet knippen (1965), Malpertius (1973) and Crazy Love (1987) are great texts for a multiplicity of readings. These are substantial contributions by Flemish cinema to auteurism in world cinema.

From a South African perspective one is struck by the sheer sensibility of a cinematic history and culture 
in the achievements of Flemish filmmakers such as Delvaux, Roland Verhavert, Guido Henderickx, Marc Didden, Dominique Deruddere and Hugo Claus. The introduction, for example, of post-war modernism to Flemish cinema by Rik Kuypers, Ivo Michiels and Verhavert in Meeuwen sterven in de haven (1955) was partially possible due to the filmmakers' knowledge of film history and great classics such as The Third Man and Odd Man Out by Carol Reed. Although classical Flemish literature seems to be an important source of inspiration for Flemish cinema in the past, achievements in the development of international cinema also had a profound influence. Movements such as the Italian Neo

realism and the French New Wave are constantly referred to by the directors in interviews on the DVDs by the Belgian Archives. Deruddere, for example, mentioned Coppola as an influence for the sumptuous visual look of Crazy Love. Henderickx referred to John Huston and his seminal film, Fat City, as an inspiration for Verbrande Brug. The importance of an international film history on a film culture is vividly highlighted here.

South African cinema under apartheid in general lacked such a sensibility because of severe censorship and inadequate distribution of a wide selection of world cinema. Severe moral censorship in the 1960s and 1970s prevented South Africans from viewing international landmarks such as Fellini's Satyricon, Bertolucci's Last Tango in Paris and 1900, Pontecorvo's The Battle of Algiers and many other films, which at that critical stage would have challenged our conceptions of sexuality, politics, race and aesthetics. As a result, most Afrikaanslanguage films communicated by means of obsolete symbols that had little multicultural communication value. They painted a one-sided and stereotypical portrait of the Afrikaner, leading to a misconception about who and what the Afrikaner was. Furthermore, the negative portrayal of blacks as a servant class in these films is a visual symbol of the deep-seated apartheid ideology. Afrikaans cinema in general also lacks the thematic and stylistic diversity of Flemish cinema during the 1970s and 1980s.

Flemish cinema is unfortunately not widely seen in South Africa. Those who are fortunate to have DSTV are able to see Dutch and Flemish films on BVN. I am making an effort to see as many films from Belgium as possible, but, it is an uphill battle. Thanks to the project of the Belgian Archives to make these classics available on DVD, I am able to see a wider selection of Flemish cinema. It is important, since I believe as in the case of the directors of these classics who were deeply influenced by various aspects of filmmaking before them, a young generation needs to know what was in existence before them. If they dismiss an entire film history and film culture, they have to know that history and to be able to contextualize the achievements by directors before them. If they want to break free from the past such as the French New Wave or the Young German directors of the 1960s they need to know their film history. Unfortunately, due to the dominance of Hollywood worldwide, especially on the screens of multiplexes in our cities, the chance for a young generation to see their own cinematic images (past and present) are becoming more and more limited.

Thanks to digital technology our post-apartheid cinema is currently enjoying a revival. But the industry also faces major challenges. Despite the establishment of a national film commission and significant positive initiatives such as the Film Resource Unit to develop audiences for South African films, local filmmakers are still struggling to find an audience for their work. The poor local performance of internationally acclaimed South African films such as A Reasonable Man and Hijack Stories leaves one with a feeling of déjà vu.

A film industry or in more ambitious terms, a national cinema, is ultimately dependent on the number of people who are willing to pay for it. Without a paying audience, whether it is cinema, television, video or new media exhibition, there can be no industry to speak of. With a total population of approximately 42 million people South Africa has a tiny cinema-going audience measured at roughly five million persons with a rapidly growing television consuming public penetrating approximately 49 percent of the total number of South African households.

In the future audience development will become more and more crucial to build audiences for the postapartheid cinema. Our film industry has been held to ransom for decades by the developed markets' funding and exhibition models, content and distribution strengths and worldwide dominance of the Hollywood studios. It has been estimated that Hollywood product dominates ninety-nine percent of screen time in South African cinemas. Local filmmakers have to compete with films by independent American, British and Australian filmmakers, as well as "art-house" films from Europe, the Middle East and Asia for the remaining 1 percent. This one percent includes films from Belgium! 
Some theatrical distributors such as UIP (United International Pictures) owned by international studios merely serve as a "courier service" between the international studios and the local exhibitors. They do not have a quota system for local content distribution and exhibition and the rationale that informs their decision to acquire and to exhibit or not to acquire and exhibit product is based on the commercial viability of the product. Criteria used to determine viability is sometimes out of touch with South African and African realities, especially if one studies the cultural role of cinema within African communities. The unfair competition and massive marketing budgets of Hollywood studio backed film releases reduce the chances of South African box-office success at the cinema level.

The situation is probably better in Belgium, but I think, Hollywood dominance is a major challenge all over Europe. For a new generation of storytellers and cinematic voices to emerge I believe they should be exposed to a sheer diversity of world cinema, as well as their own film culture and its history. These aspiring filmmakers should know where they are coming from!

I would like to conclude to refer to a short article in the Cilect News of May 2005. Renen Schorr from the Film school in Jerusalem wrote about a conference that dealt with recruiting new students to film schools. Among the speakers was Caterina D'Amico from a film school in Rome. She noted her school's conclusion that the average Italian candidate was well-versed in American films, but had only the slightest idea who Roberto Rossellini and Federico Fellini are. The school decided to tackle this matter by holding a screening of 100 masterworks of the Italian cinema, followed by an exam. As a result, the students who passed the test and enrolled in the film school received a sturdy infrastructure to their education, while the others enjoyed a fine lesson that broadened their general knowledge about their film history and culture.

Wouldn't it be great to use the DVD collection of the Royal Belgian Archives in a similar way when recruiting new students for your film schools?

I am certainly exploring similar options in South Africa...

Note: The article is based on a paper which was read at the International Forum on "Welke Toekomst voor digital audiovisueel verleden"? at Ghent, Belgium, 22 October 2005.

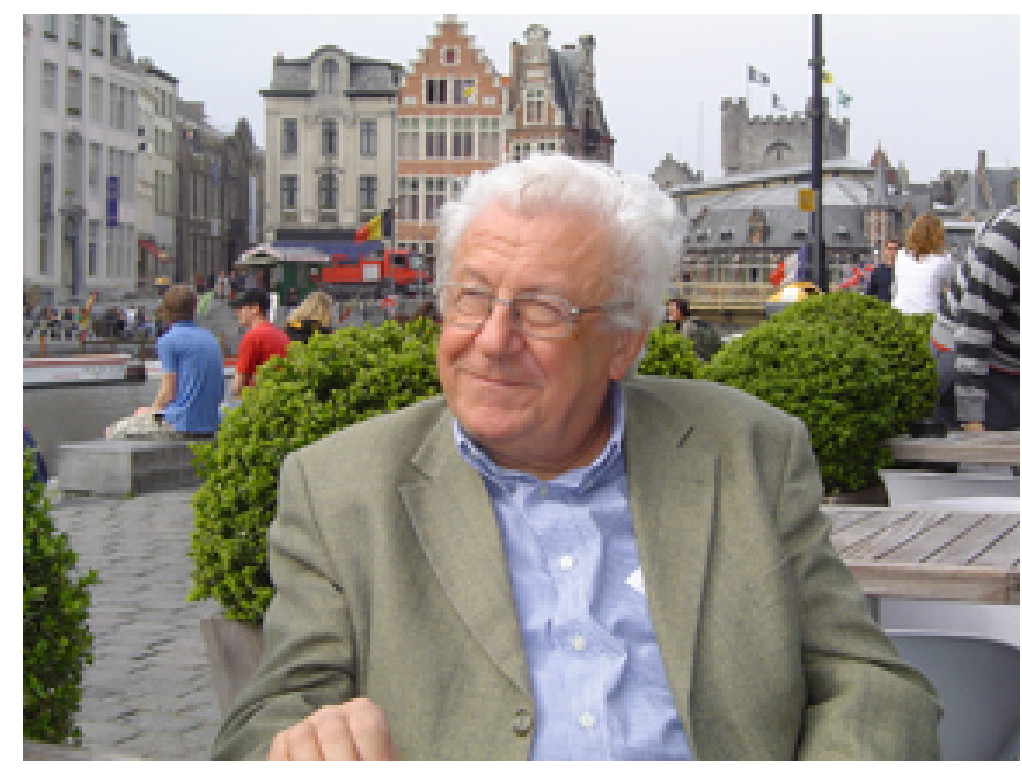

Figure 3: Prof. Hubert Dethier 


\section{Notes}

1. The director is the Antwerp-based Nicolas Provost and his award-winning medium-length film is Exoticore.

2. The concept "national cinema" is a complex one. Throughout history there has been a constant interaction between social organization and culture. By definition culture is a term which refers both to material production (artifacts) and to symbolic production (the aesthetic). In both instances, culture functions as the record and reflection of social history and the social process. Concepts of nation and national identity are also bound up in this socio-cultural functioning.

3. Filmmaker Lionel Ngakane was born on 17 July 1920 and educated at Fort Hare University College in the Eastern Cape of South Africa, as well as at the University of the Witwatersrand. From 1948 to 1950 he worked on Zonk and Drum magazines. He entered the film industry in 1950 as director Zoltán Korda's assistant on Cry, the Beloved Country. He also played the part of Absalom in the film. Soon after he left South Africa for London, where he remained until his return in 1994. Between 1951 and 1980 he acted in several films, as well as theatre and television productions. He also participated in several radio dramas. He appeared, for example, in dramas such as Mark the Hawk (1957), Two Gentlemen Sharing (1969) and The Squeeze (1977). Ngakane received international acclaim for his short film, Jemima and Johnny (1966), which was inspired by riots in Notting Hill. It portrays the political tensions of the time in the story of a friendship between a white boy and black girl. It was awarded at the Venice film festival. During his exile from South Africa, Ngakane travelled and lived in many African countries, during which time he made documentary films in Nigeria, Liberia and the Ivory Coast. In 1977 he took over as director of Golden Baobab Entertainment in Senegal, heading its film department. Ngakane later also directed documentaries about apartheid and African development. He was elected honorary president and regional secretary for Southern Africa of the Pan-African Federation of Filmmakers (FEPACI), of which he was one of the founding members. He was a consultant on A Dry White Season (1989). He was also the member of several international juries for recognised film festivals like Carthage in Tunisia, Leipzig, Edinburgh and Amsterdam. Back in South Africa during the 1990s he advised on the development of township cinemas and was part of the working group of the Film Development Strategy by the department of Arts, Culture, Science and Technology. The objective of the group was to formulate policy for a post-apartheid film industry. In 1997 he was awarded an honorary doctorate by the University of Natal. He also served on the M-Net All African Awards film competition panels, as well as in an advisory capacity for the M-Net New Direction series.

4. See publications by Blignaut \& Botha (1992), Gutsche (1972) and Tomaselli (1989).

5. Many film historians regard Jans Rautenbach as the pioneer of modern, bold South African filmmaking during the 1960s and 1970s. Together with producer Emil Nofal he made groundbreaking films at a time when South African cinema hardly reflected the socio-political realities of the country. His work is examined in Tomaselli (1989) and Blignaut \& Botha (1992).

6. In the 1970s Devenish and playwright Athol Fugard created three highly acclaimed films, Boesman and Lena, The Guest and Marigolds in August. Boesman and Lena (1973), based on Fugard's play, was the first local feature to portray the poverty and enforced removals of South Africans classified as "black" under apartheid. The Guest (1977) focuses on a small period in the life of Afrikaner intellectual, poet, writer and opium addict, Eugene Marais, going "cold-turkey" on a farm, called Steenkampskraal. Athol Fugard plays Marais as he staggers inevitably towards suicide. Devenish cuts incisively through the mythical stereotype of Marais, who believed that the existence of life is founded on pain and sorrow. This pain is the subject of a graceful, austere and controlled film, which handles its themes almost with musical skill. It is passed on and explored with almost fugue-like pattern, from person to person, from voice to voice, until Marais' point seems irrefutable. Lastly, Marigolds in August (1979) portrays the tension between a poor, black man and an unemployed black man, who is struggling to support a family in a township near Port Elizabeth. The township is a place where malnutrition is rife. It is from this place that the one man walks every morning to work in the white beach resort. His security, however, is threatened by the presence of Melton, who is looking for work. The third of Devenish's collaborations with Athol Fugard, the film was one of the few local features in the 1970s, which examined the conditions of blacks in South Africa. It became an international award winner at various film festivals, including Berlin. See Tomaselli (1989), as well as Botha Es Van 
Aswegen (1992) for a discussion on his work.

7. Publications by Balseiro and Masilela (2003), Botha and Van Aswegen (1992), Blignaut and Botha (1992), Botha and Dethier (1997), Davis (1996), Gutsche (1972), Louw and Botha (1993) and Tomaselli (1989) documented developments in South African cinema in detail. A critical overview of the fragmentation of the South African film industry during apartheid is presented in Schelfhout and Verstraeten's publication De rol van de media in de multiculturele samenleving (1998), as well as in Botha (1997, 2003a, 2004).

8. These young white directors included Ken Kaplan, Oliver Schmitz, Andrew Worsdale, as well as producer Jeremy Nathan.

9. See Botha, MP. 2003. Homosexuality and South African cinema. Kinema 19(Spring):39-64. The article provides a history of the oppression of gay voices in a cinema under apartheid.

10. Govaerts, K. Cinema $\mathscr{G}$ Apartheid: Het Zuidafrikaanse filmbedrijf en de weerspiegeling van de Zuidafrikaanse socio-politieke realiteit in de onafhankelijke film. Eindverhandeling ingediend tot behalen van de graad van Licentiaat in de Communicatiewetenschap 1991-1992.

11. Botha, MP. \& Dethier, H. 1997. Kronieken van Zuid-Afrika: De films van Manie van Rensburg. Brussel: VUB Press.

12. Ernest Claes, De Witte van Sichem, 1920.

13. Afrikaner refers to the part of the white community of South Africa who is Afrikaans speaking.

\section{References}

Balseiro, I. \& Masilela, N. (eds). To change reels: Film and film culture in South Africa. Detroit: Wayne State University, 2003.

Blignaut, J. \& Botha, MP. (eds). Movies Moguls Mavericks: South African cinema 1979-1991. Cape Town: Showdata, 1992.

Botha, MP. My involvement in the process which led to the White Paper on South African cinema. South African Theatre Journal 11(1\&2, 1997):269-285.

Botha, M. P. Overview of South African cinema, in De role van de media in de multiculturele samenleving, edited by E Schelfhout \& H Verstraeten. Brussels: VUB Press, 1998.

Botha, MP. 2003a. Current film policy in South Africa: the establishment of the National Film and Video Foundation of South Africa and its role in the development of a post-apartheid film industry. Communicatio 29(1\&2):182-198.

Botha, M. P. 2003b. Homosexuality and South African cinema. Kinema 19 (Spring 2003):39-64.

Botha, MP. "The Song remains the same": The struggle for a South African film audience 1960-2003. Kinema 21(Spring 2004):67-89.

Botha, M. P., Mare, L., Langa, Z., Netshitomboni, R., Ngoasheng, K., Potgieter, J. \& Greyling, M. Proposals for the restructuring of the South African film industry. Pretoria: Human Sciences Research Council, 1994.

Botha, MP. \& Dethier, H. Kronieken van Zuid-Afrika: De films van Manie van Rensburg. Brussel: VUB Press, 1997.

Botha, MP. \& Van Aswegen, A. Images of South Africa: The rise of the alternative film. Pretoria: Human Sciences Research Council, 1992.

Davis, P. In Darkest Hollywood: Exploring the jungles of cinema's South Africa. Randburg: Ravan, 1996.

Gutsche, T. The history and social significance of motion pictures in South Africa: 1895-1940. Cape Town: Howard Timmins, 1972. 
Louw, PE \& Botha, JR. Film: the captivating power of fleeting images, in Mass media for the nineties: the South African handbook of mass communication, edited by AS de Beer: Pretoria: Van Schaik, 1993, 151-172.

Shepperson, A. \& Tomaselli, KG. South African cinema beyond apartheid: Affirmative action in distribution and storytelling. Social Identities, 2000, 6(3):323-324.

Shepperson, A. \& Tomaselli, KG. Restructuring the industry: South African cinema beyond Apartheid. South African Theatre Journal 2002, 16:63-79.

Tomaselli, K. The cinema of apartheid: race and class in South African film. New York: Smyrna, 1989.

Acts \& Reports:

National Film and Video Foundation. Indaba 2001: Distribution, Exhibition and Marketing Report. Johannesburg: NFVF, 2001.

Nel, W. Profile 2000: Towards a viable South African Film Industry. Johannesburg: PricewaterhouseCoopers, 2000.

South Africa. National Film and Video Foundation Act No. 73 of 1997. Pretoria: Government Printer, 1997.

\section{Author Information}

Martin P. BOTHA is Associate Professor of Film and Media Studies at the University of Cape Town. He has published more than 200 articles, reports and papers on South African media, including six books on South African cinema. His most recent book is South African Cinema 1896-2010 (Bristol: Intellect, 2012). 